ROCZNIKI HUMANISTYCZNE

Tom LXIX, zeszyt $6-2021$

DOI: https://doi.org/10.18290/rh21696-3

MAGDALENA HAWRYSZ

\title{
NA STYKU RELIGII, KULTUR I JĘZYKÓW, CZYLI O POLEMICZNYCH ASPEKTACH PATERYKONU SYLWESTRA KOSSOWA
}

\section{AUTOR I DZIEŁO}

Rzeczpospolita Obojga Narodów to rozbrzmiewająca ożywioną dyskusją agora, na której ścierały się poglądy społeczne, kulturowe, polityczne, religijne wreszcie. Te ostatnie wywołane były ruchem reformacyjnym zainicjowanym przez Marcina Lutra oraz - co tu szczególnie istotne - unią brzeską. Wśród autorów podejmujących katolicko-prawosławną dyskusję wyznaniową był Sylwester Kossow, wychowanek kolegium jezuickiego w Lublinie, student m.in. Akademii Zamoyskiej, wykładowca retoryki i filozofii w Kolegium Kijowsko-Mohylańskim, przełożony ławry Peczerskiej, obrońca prawosławia (Łużny, Sylwester Kossow 326). W jego dorobku znajdują się utwory reprezentujące nieliczne zachowane do dziś polonika kijowskie ${ }^{1}$, czyli teksty napisane prymarnie w języku polskim, których autorami są Rusini. Do szerszej świadomości lingwistów, również historyków polszczyzny, weszły one dzięki prowadzonym od dekady badaniom Jolanty Klimek-Grądzkiej (Klimek; Klimek-Grądzka). Piśmienne świadectwa wielokulturowości dawnej Rzeczpospolitej, wieloaspektowych relacji polsko-ruskich stały się podstawą studiów, które ujawniają specyfikę tej odmiany polszczyzny ze

Dr hab. MAGDALENA HAwRYSZ, prof. UZ - kierowniczka Zakładu Językoznawstwa Instytutu Filologii Polskiej Uniwersytetu Zielonogórskiego; adres do korespondencji: Uniwersytet Zielonogórski, Instytut Filologii Polskiej; al. Wojska Polskiego 69, 65-762 Zielona Góra; e-mail: mhawrysz@uz.zgora.pl. ORCID: https://orcid.org/0000-0001-6049-635X.

${ }^{1}$ Jak podaje Jolanta Klimek (Konstrukcja accusativus cum infinitivo $w$ XVII-wiecznych polonikach kijowskich 92) do dziś dostępnych jest 17 tytułów spośród 22 lub 26 pierwotnie istniejących. 
szczególnym uwzględnieniem płaszczyzny systemowej, w tym leksykalnej. W mniejszym stopniu zwracano dotąd uwagę na szeroko rozumiane zjawiska stylistyczne. Chcąc - przynajmniej w jakimś stopniu - wypełnić tę lukę, w niniejszym opracowaniu postanowiono się przyjrzeć jednemu $z$ utworów pod kątem obecnych $\mathrm{w}$ nim cech tekstu polemicznego. Obserwacji poddano szczególny zabytek ze zbioru poloników kijowskich, tj. Paterikon abo żywoty ss. Oycow pieczarskich Sylwestra Kossowa ${ }^{2}$. Jest to polskojęzyczna wersja średniowiecznego utworu hagiograficznego zatytułowanego Pateryk kijowsko-pieczerski. Dla filologicznego porządku warto przypomnieć, że jest to powstający przez kilka stuleci i uzupełniany przez wielu autorów zbiór hagiograficznych opowieści o żyjących w pieczarach mnichach monasteru kijowskiego. Warto nadmienić, że zabytek ten zyskał swoją drukowaną postać dopiero w 1635 roku, właśnie w poddawanej tu analizie wersji.

$\mathrm{Na}$ polemiczne nacechowanie niektórych partii tekstu zwracają uwage Ludmiła Nodzyńska ${ }^{3}$ oraz Ryszard Łużny ${ }^{4}$. Celem niniejszego szkicu będzie wskazanie generycznych elementów polemiki z poziomu kompozycji i pragmatyki tekstu oraz identyfikacja podporządkowanego im repertuaru środków językowych realizujących perswazyjne cele tekstu polemicznego.

${ }^{2}$ Pełny tytuł brzmi: Paterikon abo żywoty ss. Oycow pieczarskich. Obszyrnie Stowieńskim językiem przez Swiętego Nestora Zakonnika y Latopisca Ruskiego przedtym napisany. Teraz zaś z Greckich, Laćińskich, Stowiańskich y Polskich Pisarzow objaśniony i krocey podany przez Wielebnego w Bogu Oyca Silvestra Kossowa, Episkopa Mśćisławskiego, Orszańskiego y Mohilewskiego. Cytaty przywołuje się z tego źródła (pełen adres zob. Literatura podmiotu), rezygnując z zaznaczania $a ́, \int$ oraz 3 . Liczba w nawiasie oznacza stronę lub kartę, nawias kwadratowy sygnalizuje stronę nieliczbowaną. Wytłuszczenia w cytatach pochodzą od autorki.

${ }^{3}$ Badaczka pisze: Palinodię przypominają części polemiczne: wstęp Do czytelnika prawosławnego, poświęcony wywodom dotyczącym świętości ojców pieczerskich, pozostających w ciele „niespróchniałym” i w łączności z Kościołem Wschodnim, Apendix o pięciokrotnym chrzcie Rusi (poczynając od podanej serio latopisarskiej legendy o pobycie św. Andrzeja apostoła na Rusi) i Chronologia o prawosławnych metropolitach ruskich, gdzie m.in. podobnie jak u Kopysteńskiego, rozpatrzony jest problem trzech metropolitów Rusinów niezależnych od patriarchy konstantynopolitańskiego (Nodzyńska, O pierwszym 223). Ta sama uwaga pojawia się w (Nodzyńska, Pateryk Kijowsko-Pieczerski 51).

${ }^{4}$ U znawcy życia i twórczości Kossowa czytamy: „Obecność w tytule obu tych nazwisk, obok innych też elementów nowej redakcji szacownego zabytku, nadawała tej pozycji wydawniczej specjalnego splendoru, zwłaszcza że przygotowana i ogłoszona ona była z określonym ideowym wydźwiękiem, jako wystąpienie polemiczne w obronie prawosławia w ogóle, a praw, zasług i aspiracji cerkwi kijowskiej w szczególności [...]" (Łużny, Kijowski siedemnastowieczny wariant 38). I jeszcze nieco dalej: „Przyjęły one postać bądź specjalnego wstępu do całości oraz wprowadzeńprzedmów do poszczególnych żywotów, a także osobnych traktatów o charakterze polemicznym, bądź też rozlicznych wstawek, uściśleń, porównań, paralel i odautorskich uogólnień, zwłaszcza emocjonalnie i dyskursywnie zabarwionych zwrotów do czytelnika-słuchacza” (40). 


\section{GŁÓWNE POJĘCIA OPERACYJNE ANALIZY}

Dla uzasadnienia podejmowanych niżej metod analizy niezbędne jest wyjaśnienie głównych pojęć sterujących. Polemikę rozumie się tu jako złożony gatunek mowy stanowiący autorską wypowiedź w ważnej społecznie kwestii wywołaną ujawnioną różnicą poglądów, którego celem jest obalenie stanowiska przeciwnika oraz propagowanie wykładu pozytywnego, czyli własnych przekonań. W zakresie kompozycji ujawniają się zatem znane z retorycznego ukształtowania wypowiedzi deliberatywnej elementy refutatio (zbijanie sądu opozycyjnego) i probatio (uzasadnianie własnego zdania). Przedmiotem zainteresowania tak rozumianej polemiki nie będzie jednak sfera inwencyjna, czyli ideowa zawartość argumentacji, lecz szeroko rozumiana warstwa elokucyjna, czyli słowne ukształtowanie wypowiedzi, traktowane jako narzędzie retorycznego przekonywania. W jej obręb wchodzą strategie komunikacyjne, czyli świadome, prowadzące do realizacji zamierzonego celu pozajęzykowego działania mowne realizowane za pomocą aktów mowy, ujawniające się również na poziomie kreowania wizji świata, wyborów leksykalnych, operacji składniowych, wreszcie na płaszczyźnie semantycznej ${ }^{5}$. Zgodnie zatem $\mathrm{z}$ powyższym $\mathrm{w}$ podejmowanych $\mathrm{w}$ niniejszym opracowaniu analizach zostaną zastosowane instrumenty $\mathrm{z}$ zakresu retoryki, ale także tradycyjnej stylistyki, kulturowo zorientowanej lingwistyki oraz pragmatyki tekstu.

\section{ELEMENTY STRUKTURALNE POLEMIKI}

Zaznaczyć trzeba od razu, że Paterykon nie jest generyczną polemiką sensu stricto, nie taki bowiem był cel podstawy thumaczenia. Przypomnijmy, że to utwór hagiograficzny, który realizował, co oczywiste, cele panegiryczne, edukacyjne i dydaktyczne. Jednak przeróbka Kossowa, uzupełniona o kilka autorskich fragmentów, a także rozsiane w tekście drobne uwagi wyraźnie wskazują, że traktat ten pisany był również z myślą o wyzyskaniu go w dyskusjach z wyznaniowymi oponentami, zwłaszcza z przeciwnikami relikwii i obrazów (ikon) oraz zwolennikami unii Kościoła greckiego i rzymskiego. Ilustracją tej tezy są wypowiedzi oceniające z wyraźnie wyrażoną krytyką

\footnotetext{
${ }^{5}$ Zaproponowane definicje pochodzą z opracowania Magdaleny Hawrysz. Rozumienie wszystkich przywoływanych w opracowaniu pojęć z zakresu retoryki przyjmuje się za Mirosławem Korolką.
} 
adwersarzy zawierającą się $\mathrm{w}$ nacechowanych negatywnie leksemach heretyk, zheretyczaly, zadawać ('zarzucać, wyrzucać, wymawiać') oraz w nakazach wskazujących przykre konsekwencje niepożądanych z punktu widzenia autora zachowań, co jest realizacją erystycznego argumentu ad baculum:

Ucz się heretyku, że obrazy są wdźięczne Matce Bożey. A ty Prawosławny Narodźie, na obrazy dla ozdoby Cerkwie Pańskiey kosztu iakoś zwykł nie żałuy, abyś tęż zapłatę, ktorą y ten święty Erasmus w niebie odźiedźiczył, ktoreyći wiernie sprzyja. (154)

ZE reliquie Swiętych, iako przyiaćioł Bożych maią być in summo honore, y że niesprochniałe ćiała, ktore były Cerkwią Ducha ś. uczćiwośći są godne, nigdy dotąd tylko zheretyczały in dubium wokował, Czytelniku Prawosławny. (1)

A iesliby Czytelniku Prawosławny kto zadal, że nie masz czego iuż wenerować w ćiałach po wyszćiu dusze z nich. Odpowie za ciebie Ambroży ś. słuchay. (3)

Który z prostakow Relquiy świętych nie szanuie, niech będzie exkomunikowany: który zaś z Klerykow, niech będzie zrzucony. (Cc3)

A tak wszyscy Prawosławni ludzie, w pobożnośći kochających się Zakonnikow szanuyćie; bo widźićie że się za nich iako za przyśięgłych sług swoich Chrystus Pan zwykł mśćić. (108)

Wśród komponentów o wyraźnie polemicznym charakterze jest przedmowa zatytułowana Do czytelnika prawosławnego ${ }^{6}$. W tym fragmencie Paterykonu znajduje się część wydzielona śródtytułami Obiectio I, II, III itd. $(5,7,8)$, w której dowodzi się świętości i cudowności relikwii ojców pieczarskich ${ }^{7}$. Jest ona poprzedzona zapowiedzią skierowaną do tych, którzy usiłują zaćmić splendor mnichów:

A że przedsię znayduią się tacy, ktorzy Ecclypsim twemu (Ziemio Kijowska - uzup. aut.) szczęśćiu obiekcyami utworzyć tentuią, do nich się tak odzywam. (5)

Kolejne segmenty przedmowy przybierają postać precyzyjnego wywodu ustrukturyzowanego na wzór dialogu, pierwotnej formy dyskusji i wszelkiego nauczania. Autor przywołuje kolejno cztery formułowane pod adresem relikwii pieczarskich kontrowersje (obiekcyje), po czym odpiera zarzuty, każdorazowo to zapowiadając: Odpowiadam $(5,7)$, Na to taka daie repike (8), Odpowiadam z Okrzczenia Samego Rvsi (8). W tej części fundamentalną rolę

\footnotetext{
${ }^{6}$ Nadmienić przy tym warto, że tytułowy atrybut adresata nie funkcjonował w XVII wieku w znaczeniu dzisiejszym, lecz oznaczał człowieka prawowiernego.

${ }^{7} \mathrm{~W}$ literaturze przedmiotu adiectivum występuje w różnych postaciach: peczerscy, pieczerscy, pieczarscy. Tu zdecydowano się na formę pieczarscy zgodną z postacią obecną $\mathrm{w}$ analizowanym zabytku oraz uzasadnioną słowotwórczo.
} 
w perswazyjnym działaniu słownym odgrywa argumentacja w postaci sylogizmów; dla przykładu:

zarzut: ciała ojców pieczarskich są zabezpieczone przed zepsuciem ziołami
przesłanka większa I: zioła wydają zapach
przesłanka większa II: ciała zabezpieczone ziołami pachną
przesłanka mniejsza: ciała ojców pieczarskich nie wydają zapachu
wniosek: ciała ojców pieczarskich nie są zabezpieczone ziołami // skoro ciała nie
pachną, zioła straciły moc, nie mogą więc zabezpieczać ciał ojców pieczarskich (8).

Jak wskazuje przywołany przykład, rolę przesłanek większych w logicznych konstruktach pełnią powszechnie występujące w przyrodzie zjawiska, np. rozkład organizmów w wysokiej temperaturze ${ }^{8}$, czy też codzienne czynności gospodarskie, jak stosowanie ziół. Jako dobrze znane przeciętnemu człowiekowi, mają duży ciężar dowodowy, są zatem wysoce skuteczne $\mathrm{w}$ dowodzeniu propagowanej racji.

Następnym komponentem Paterykonu o walorach polemicznych jest Appendix o pięciorakim okrzczeniu Rusi (11-16). Wewnętrzne rozczłonkowanie tej części ujawnia się na powierzchni tekstu w postaci numerycznego zaznaczenia etapów wywodu (cyfrą lub słownie): 1. (11), Powtore (12), Potrzecie (12), Poczwarte (13), Naostatek (14). Te metajęzykowe wykładniki kategorii retorycznych o charakterze prognostycznym ${ }^{9}$ porządkują logicznie bieg uzasadnienia, zapowiadając kolejne argumenty. W tej części fundamentalną rolę w dowodzeniu spełnia powoływanie się na zapisy historyków. Wśród autorów przywoływanych kronik i annałów znaleźli się dziejopisarze zarówno ruscy, jak i polscy, wreszcie europejscy ${ }^{10}$. Zabieg ten jest szczególnie cenny perswazyjnie, gdyż po pierwsze, osadza argumentację w źródłach, utworach o charakterze historiograficznym, a więc naukowym, co z zasady ma zapewnić wiarygodność, po drugie, wielość i wszechstronność pochodzenia

\footnotetext{
${ }^{8}$ Seria przesłanek z doświadczenia służących udowodnieniu, że kości mnichów pieczarskich nie podlegają zepsuciu z powodów nadprzyrodzonych wygląda tak:

Znak iest, że Lećie gdy ćiepło pozwierzchowne panuie, snadniey się rzeczy psuią y gniią, kwaśnieią, abo gdy częste z południa wiatry są, a niżeli w źimie, ktorego żimno one krępuie (6)

Znak, że te rzeczy, ktore są barzo źimne iako lod, y metalla abo kruszcze nie prochnieą (6)

Znak, że rzeczy, ktore są in motu nie rychło prochnieią y psuią śię; te zaś ktore stoią, snadnie gniią, y zepsowaniu podległe; iako każdy w wodźie ćiekącey w studni widźieć może (6).

${ }^{9}$ Tak nazywa tego rodzaju elementy Anna Duszak (149-160).

${ }^{10}$ Kossow przywołuje dzieła historiograficzne autorstwa Cezarego Baroniusza (włoskiego historyka i hagiografa), Nestora (ruskiego latopiśca, mnicha pieczarskiego), Jana Zonarasa (kronikarza bizantyjskiego), wreszcie historiografów opisujących polskie dzieje: Abrahama Bzowiusza (dominikanina, historyka Kościoła), Jana Długosza, Aleksandra Gwagnina, Marcina Kromera, Macieja Stryjkowskiego, Bernarda Wapowskiego.
} 
autorów z powodzeniem $\mathrm{w}$ oczach odbiorcy pełni rolę gwaranta tego, że utwory nie są dobrane tendencyjnie, co dodatkowo wzmacnia obiektywizm argumentacji. O tym typie dowodzenia będzie jeszcze mowa niżej.

Charakteru polemicznego można upatrywać także w dwóch finalnych częściach Paterykonu, tj. w Chronologii prawosławnych metropolitow ruskich (169-181) oraz Rejestrze ([Aa4v-Ee3v]). Pierwsza z nich to rodzaj kalendarium podającego wszystkich zwierzchników Cerkwii prawosławnej. W perspektywie cech perswazyjnych tekstu zwraca uwagę fakt, że katalog jest poprzedzony przypomnieniem, iż ruscy metropolici podlegali jurysdykcji patriarchy Konstantynopola, nie zaś papieża. Informacja ta ma wartość argumentu z tradycji:

I abyś wiedźiał, iż od tey Swiętey Stolice (Konstantynopola - uzup. autora) Ruś po odrodzeniu się od Wody y Ducha, a nie odo inny sobie nie należney, aż do dźiśieyszego dnia Matetropolitom swym też Sacrę brała. A tych taki komput w Pomnikach naszych Russkich. (169)

Reiestr z kolei to nic innego jak spis treści, zgodnie więc z genologicznym oczekiwaniem zostały $\mathrm{w}$ nim wskazane strony, na których czytelnik odnajdzie wydarzenia z życia poszczególnych bohaterów-świętych mnichów pieczarskich, niekiedy bardzo drobiazgowo rozpisane. Można jednak znaleźć w Rejestrze i takie miejsca, gdzie hasłem przedmiotowym jest kwestia mogąca się stać przedmiotem polemiki, jak choćby seria haseł związanych $\mathrm{z}$ cudami [Bb3], które w spisie podane są w formie faktu.

\section{POLEMICZNE STRATEGIE KOMUNIKACYJNE}

Polemiczny charakter Paterykonu wyraźnie widać w działaniach również na innych poziomach kształtowania tekstu. Ogląd materiału pozwolił tu wyróżnić kilka strategii komunikacyjnych, których celem jest zbudowanie sugestywnej wizji monasteru i zamieszkujących go zakonników. Tak kształtowany obraz ma kluczowe znaczenie w części probacyjnej polemiki, za jaką można uznać żywoty świętych pieczarskich. Wspomniana sugestywność wynika $\mathrm{z}$ dwóch przeciwstawnych w charakterze mownych działań (globalnych strategii komunikacyjnych): $z$ jednej strony jest to uwiarygodnienie treści (na które składa się powoływanie się na źródła historiograficzne i dokumenty oraz dokonywanie zabiegów etymologizujących), z drugiej zaś apoteoza osób i miejsca (którą realizują strategie osadzania przekazu w przeszłości, odwołanie do genealogii, maksymalizacja cnót świętych, sakralizacja zakonnej rzeczywistości). Ich charakterystyki dokonuje się poniżej. 
Sylwester Kossow bardzo zadbał o to, by jego utwór miał wartość historyczną, czyli był wiarygodny. Podstawowym zabiegiem autora, aby osiągnąć rzetelność przekazu i jego obiektywizm, jest powoływanie się na zróżnicowane źródła historyczne, w czym można upatrywać argumentum ad verecundiam. Nieustanne odwołania do kronik, roczników, latopisów itp. są sygnowane w toku opowieści, np.

Okrzczenie Ruśi doskonałe y powszechne za okrzczeniem się Włodźimierza Swiatosławowicza Monarchy Ruskiego, według naszych Dyptychow, [...] stała się praecise Roku Tyśiącnego: a według Baroniusza, Tyśiąc osmego (8-9)

iako świadczy starodawny nasz Latopisca Slowiański Nestor, y inszy historykowie (12)

według Wapowiusa y Bielskiego (55)

świadczy Długosz w te słowa (14)

Miechowius pisze (56)

wspomina Strykowski (110).

Wskazywanie źródeł stanowi także istotną część marginaliów, np.

Dlugos: in Annal: suis (14)

Sricouius lib: 4 fol: 148 (12)

Zonara Annaliū tomo 3. (12)

Wreszcie na końcu dzieła znajduje się lista autorów (notabene jawi się ona jako niekompletna, jeśli zestawić ją z pojawiającymi się w treści Paterykonu nazwiskami), z których czerpano informacje zarówno przy pisaniu żywotów ojców pieczarskich, jak i tworzeniu spisu metropolitów ([Ee4]).

Metoda eksplicytnego wskazywania dzieł naukowych, a więc mówiących o faktach, nie zmyśleniach, ma zasadniczą siłę argumentacyjną w sytuacji polemicznej. Co więcej, ta moc nie ogranicza się do partii refutacyjnych (zwłaszcza przedmowy i dodatku, zob. wyżej), ale obejmuje swym oddziaływaniem także same żywoty. I w nich bowiem znajdują się liczne wtręty poświadczające obecność w źródłach opisywanych przez autora faktów, które niejednokrotnie mogą się wydawać nierzeczywiste ${ }^{11}$. Nadto, autor zostawia w tekście ślady porównywania dokumentów (np. wedtug Kronik tak, Russkich, jako y Polskich 55) i - co ważne dla zachowania wiarygodności i obiektywizmu - unaocznia ujawnione między nimi różnice, nie przemilcza też zauważonych w nich braków (np. ale o tym Kroniki Polskie milcza 22, Kroniki zaś nasze Russkie o tych Waragach wywodu doskonatego nie daia 24).

\footnotetext{
${ }^{11}$ Inna sprawa, że taka była podówczas poetyka dzieł historiograficznych. Prócz twardych, poświadczonych faktów w utworach dziejopisarskich znajduje się wiele opowieści fantastycznych.
} 
Wzmocnienie wiarygodności przekazu jest nieustannie przez Kossowa podsycane przywoływaniem także innych pism: po pierwsze, o obiektywnie niepodważalnej randze dokumentów, jak autentyczne rękopisy $(179,180)$, po drugie, pełniących funkcję dowodów we wspólnocie religijnej, jak: Stary Testament (1), postanowienia konsylium kartagińskiego (2), pisma doktorów Kościoła (2).

W obszarze działania obliczonego na uwiarygodnianie treści mieszczą się także wywody etymologiczne. Ich perswazyjnej wartości można upatrywać w tym, że wskazują one logiczne uzasadnienie dla nieoczekiwanych, niezrozumiałych, niekiedy dziwnych nazw lub przydomków, por.

\begin{abstract}
A osobliwie kazał (Władysław Światosławowicz - uzup. autora) okrzćić synow swoich dwanaśćie [...] y odtąd tę gorę nad Dnieprem, gdzie się oni krzćili, prostacy y po dziś dzień Chrzeszczatykiem zową. (15-16)

A Dzieśięćinną dla tego ta Cerkiew była nazwana, iż wszystka Ruska Ziemia dźieśięćinę na tę Cerkiew dla ochędostwa y wychowania Duchownych dawała (16) Odtąd tedy nazwisko ma Monaster Pieczarski, iż pierwey w pieczarach żywot Zakonniczy pędzili (20)

Za to złoto y srebro iest zmurowana Kaplica na imię święte ${ }^{\circ}$ Iana Krzćićiela, ktorędy teraz chodzą na Chor Cerkiewny, ktory pospolićie zowią Połata: a to dla pamiątki tego Iana Szlachćica, y syna iego Zachariasza, ktory da srebro y złoto na chwałę Bożą (89)

Gdy tedy tak statecznie ćiasną drogą Zbawićiela szukał, przezywany był Lobodnikiem, że zawsze miasto kosztownych y wymyślnych potraw dla Chrystusa teto gorzką łobodę iadał (117)

miał bydź ten skarb Waragow, bo oni naprzod Pieczarę wykopali byli, dla czego y Warazką ta Pieczara y do tych czas się zowie (129)
\end{abstract}

Tropienie ukrytych w słowach znaczeń służyło budowaniu szczególnej aury wokół miejsca i osób, sprzęgając losy monasteru i mnichów z historią całego państwa, losami przedstawicieli elit rządzących, wreszcie z dziejami Europy. Pozwalało to eksponować szanowaną podówczas wiekowość, a tym samym nobilitować osoby i miejsca, przydawać zakonnej wspólnocie splendoru, dowodząc jej dawności, nieprzerwanego trwania, funkcjonowania w zgodzie z porządkiem świata ${ }^{12}$. Dawność jest zresztą podkreślana również przy innych okazjach, a leksemy stary (tytuł od Roxolanow starych [...] zawźią [A4], starożytny ( $w$ starożytnej wierze $z$ starożytnych Przodkow [A3], starożytnych Swiętych [A3v]), starodawny (iako świadczy starodawny nasz

\footnotetext{
${ }^{12}$ Okres, w którym powstało analizowane tu dzieło, jest przykładem postfiguratywnego typu kultury, w której przeszłość darzy się szczególną atencją (Mead 23-58).
} 
Latopisca Slowiański Nestor 12), starowieczny (wedtug starowiecznego naszego Kronikarza ś. Nestora Zakonnika Pieczarskiego 55) nabierają cech wyrazów pozytywnie wartościujących.

Te uwagi przenoszą rozważania na płaszczyznę drugiej globalnej strategii komunikacyjnej, za jaką uznano w niniejszym szkicu apoteozę osób i miejsca. W jej obrębie ze wskazanym wyżej zabiegiem wpisywania przekazu w dawność współbrzmi przywoływanie genealogii. Znamienne jest, że podobnie jak w Koronie chętnie powoływano się na starożytnych przodków, tak i na Rusi istniał ukraiński (ruski) wariant sarmatyzmu (Skrukwa 67). W konsekwencji ziemie te nazywano Roksolania, a jej mieszkańców Roksolanami. Świadectw ujawnionego w warstwie onomastycznej przeświadczenia o antycznym rodowodzie znajduje się w utworze Kossowa niemało, oprócz bowiem etnonimu Rusacy (13) czy omownego miana naród ruski (Przezacny Narodźie Russki 158), pojawiają się określenia Roksolanie (Roxolanie 13), naród roksolański (Roxolanski narod 11, Przezacny Narodźie Roxolański 146, wielkiego narodu Roxolanskiego 15), państwo roksolańskie (Roxolanskie Państwo 163).

Najszerzej apoteoza świata monastycznego realizuje się w obrazie mnichów pieczarskich. Jako że gatunkowo tekst należy do literatury panegirycznej, nie może dziwić obecny tu na wielu poziomach podniosły ton. Ujawnia się on już w sposobach nominacji zakonników. Prócz biblijnych nawiązań (postuszna owieczka 18, pasterz z pozytywnym atrybutem prawdziwy 30 lub czuly 34) pojawiają się również metafory i peryfrazy z kręgu sakralnego (przyiaćiot Bożych 1, drudzy Aniołowie 17, Mąż święty 43, Ugodnikow Bożych 163) oraz militarnego (zakonnych rycerzow 25, prawdźiwy Chrystusow żolnierz 73). Zdarzyło się również nagromadzenie gloryfikujących określeń, które brzmią niczym wezwania w litanii: Odchodźisz od nas czystośći Miłośniku, Zwierćiadlo dobrowolnego ubostwa, Przyktadźie postuszeństwach (151).

W charakterystyce mnichów pieczarskich na plan pierwszy wysuwa się co oczywiste - pojęcie pobożności. Na płaszczyźnie językowej jest ona ujmowana dwojako. Po pierwsze, wyraża ją uogólniona, syntetyczna charakterystyka, dla której ośrodkiem staje się leksem cnota, np.

człowiek [...] w cnotach nie pośledni (18)

Mąż cnot wszytkich pełny (31)

na ktorym urzędzie kapłańskim wysokie cnoty w nim pokazywały się (91)

Po drugie, pobożność zyskuje szczegółowe dookreślenie w postaci wielości pozytywnych cech przypisywanych mnichom. Konieczne jest przy tym za- 
strzeżenie, że niektóre pojęcia nabierają odmiennego nacechowania ze względu na specyfikę systemu wartości funkcjonującego w określonej światopoglądowo wspólnocie, jaką jest zakon. Wśród ewaluatywów dodatnich znajdują się wartości:

- transcendentne - wyrażone leksemami z rdzeniem -święt-, -bog-:

Mąż święty (43), wielkiego tego y świętego Męża (49), święty Zakonnik (139), świętych Oycow Pieczarskich (122), świątobliwość, Xśiążęta, Panięta, y Senatorowie Ruscy czćili (34), porządnie y świątobliwie sprawował (57), wielce świątobliwego człeka (20)

Zakonnicy pobożni (148), słysząc o wielkiey pobożnośći ANTONIEGO ś. (19), Liczy Kiow setnicami wiele innych gwiazd pobożnośći (10), Gruchnęło pobożne żyćie ś. TEODOZEGO ([28])

- poznawcze, gdzie cnotą jest bycie głupim w oczach świata, mądrym zaś dla Boga:

oblokszy się włośienicę, począł bydź dobrowolnie dla Chrystusa głupim y szalonym (81)

- estetyczne - w tym kręgu eksponuje się prostotę:

obaczył błoto wielkie, w ktore skoczywszy, prędko zrzućił w one świeckie kosztowne szaty, y nogami ieszcze podeptał (73)

Rozkazał lepak kupić sobie skorę surową koźlą, y uszyć na kształt woru na śiebie (78-79)

- moralne - uzewnętrznione na płaszczyźnie języka leksemami cnota, czystość, miłosierny, taskawy:

sowićie się starał w tych cnotach zbogaconym bydź (21), Chwyćił się tedy cnot nie leniwo święty Grzegorz (103), innych Zakonniczych cnot był nieleniwy (116)

był wielkim naśladowcą w pokorze, y w czystośći, y we wszytkich cnotach ś. Teodozego (57), zwierćiadłem był czystośći, słońcē posłuszeństwa, krzyształem ubostwa $(20-21)$

wielce milośierny y laskawy (30)

- obyczajowe, jak posłuszeństwo i pracowitość:

postami y posłuszeństwem ustawicznym (85)

w pośćie trwałego, w Modlitwach statecznego, do prac nieleniwego (137)

nie byl prożnuiącym żadnego dnia, nocy zaś na Bogomyślnośći y gorących modlitwach pędźił (91) 
- odczuciowe, czyli milczenie, post, ekskluzja, rezygnacja z dóbr materialnych i mycia:

To dźiwna, że przez dwie lećie ten ś. Izaak ani chleba, ani wody zażywal, ani iakieykolwiek potrawy, tylko iako głuchy a niemy leżał (80)

y był na tym mieyscu przez trzy dni nie wychodząc, ani iedząc, ani się ubieraiąc, tylko w iedney włośienicy będąc (74)

Przez dwie lećie nie iedzący nie piiąc cudownieyszym został ś. Izaaak (80 marg.) nadto zamknął się w ćiasney Pieczarze w Celli barzo małey, ktorey ledwo było na cztery łokćie, y w teyże łzami zawsze nawyższego prośił, nic więcey nie iedząc, tylko Proshorę iednę na dzień y trochę wody piiąc (78-79)

Nie leżał święty Izaak na łożku, ale śiedząc mało co snu zażywał, nigdy na świat nie wychodząc; a trwał w tym przez lat śiedm (79)

opuśćiwszy delicye świata, ostry żywot w Pieczarach przyiął (73)

marnośći świeckie w podept puśćił (96), wszystkiemi świata marnośćiami łatwo pogardził (146)

nadto nigdy go żaden nie widźiał aby się miał myé, wyiąwszy twarzy y rąk (33)

Charakterystyczną cechą wyidealizowanego portretu bohaterów jest spiętrzanie ich zalet $\mathrm{w}$ postaci wyliczenia, co wzmaga intensywność panegirycznego wydźwięku opisu, np.

one dwie wielkie światła, Słońce y Mieśiąc, na horyzonćie Kiowopieczarskim świątobliwośćią życia, modłami,

postami, hymnami calodziennymi y calonocnemi świećić poczęli (58)

święty Antoni włośienicą, postem, niespaniem, twardo leganiem etc. nieprzyiaćiela dusz y zbawienia ludzkiego molestował (97)

y odszedł z ćiała do onych pożądanych radośći; na ktore postami, włośienica,

modłami, płaczem, y wszelakimi Bogu miłemi cnotami zarabiał, iako wierny sługa y żołnierz Chrystusow (102)

przez wiele lat w pośćie, w niespaniu, y modłach ustawicznych przebywał (123)

Prócz amplifikacji w repertuarze środków stylistycznych wykorzystywanych w opisie cnót zakonników pojawia się antyteza, eksponująca pożądany rozdźwięk między sacrum a profanum, tzn. między życiem zakonnym a światem zewnętrznym, np.

miasto wielkich bogactw, ubostwo: miasto purpury, włośienicę: miasto rozkosznych potraw leśne korzonki: miasto wielkich sług orszakow, na puszczy drzewa: miasto wdzięcznych melodii Muzycznych, mile leśnych ptaszkow szczebiotania: miasto kosztownych pośćieli, pod niebem otwartym źiemię trawą przyodźianą, nakoniec, miasto Oyca y Matki miłey, miasto pokrewnych ćichą puszczę obrał sobie (146)

Wskazany repertuar cnót (zaznaczmy - niepełny) składa się na to, co autor nazywa ostrym żywotem, a co należy rozumieć jako ascezę. Intensywność 
zakonnych ciężarów (72) i trud ciasnej drogi (102) są podkreślane różnorodnymi, choć skonwencjonalizowanymi określeniami wyrażającymi skalę działań i stopień zaangażowania mnichów w praktyki zakonne - ich modlitwy są gorące, trwają całe dnie i noce, a posty są wielkie i ustawiczne, por.

gorące modły (42), Boga się gorąco modlił (23), iako się modlił gorąco Zbawićielowi (69), gorąco się Panu Bogu modlił (70), gorąco się w Cerkwi modląc (70) w ktorȳ zakonnym żyćiu czule w codziennych y conocnych modłach znachodząc się (90)

barzo gorących dniem y nocą modlitw (103)

był zwykł całą noc hymnami się y modłami zabawiać (103)

w wielkim pośćie się kochał: bo aż do śmierći swoiey, żadnych pokarmow nie zażywał, iedno trochę chleba y wody (68)

ustawicznemi postami, modłami, niespaniem, włośienicą na wieczne one radośći zasłużył (68)

Sposobem na podkreślenie wyjątkowego sposobu życia mnichów pieczarskich jest również nierzadko używany topos zdziwienia i podziwu wywoływanego u największych ówczesnego świata, którzy często osobiście stawiali się w zakonie, oddawali mnichom cześć i prosili ich o błogosławieństwo:

Zakonnicy pobożni, ostry żywot swoy w Pieczarach, z wielkim wszytkich podźiwieniem prowadzili (71-72)

świątobliwość, Xśiążęta, Panięta, y Senatorowie Ruscy czćili (34)

wiele Panow [...] y pokłon mu zśiadszy $\mathrm{z}$ koni $\mathrm{z}$ wielką rewerencyą na drodze oddawali (34)

nastąpił na stolicę Kiowską syn iego Izasław, ten słysząc o wielkiey pobożnośći ANTONIEGO ś. zwykł był często do niego przychodzić o y błogosławienstwo prośić (19)

Gruchnęło pobożne żyćie ś. TEODOZEGO, o ktorȳ uwiadomiony; przychodził donie $^{0}$ Xiążę Izasław często z Synaczkiem swoim małym pieszo z Kiowa ([28])

Apoteozie monasteru i mnichów służy także strategia sakralizacji, co rozumie się tu jako stałą i widomą dla świeckich obecność świata nadprzyrodzonego. W cerkwi śpiewają aniołowie (35), a od obrazów bije światłość (93). W treści Paterykonu objawia się to również przez liczne cuda, których dokonują mnisi, takie jak rozmnożenie pożywienia (40), uzdrowienia (97), sprowadzenie deszczu w czasie suszy (143-144), uszycie włosienicy, która chroni przed ciosami na wojnie (152) i „,wiele inszych wielkich cudów” (144).

Ponadto Kossow upowszechnia legendy przydające splendoru ławrze Peczerskiej. Jest wśród nich przekaz o „cudotwornym” (jak pisze autor) obrazie Najświętszej Marii Panny, który stał się inspiracją do założenia cerkwi (90) czy o pasie Jezusa ofiarowanym przez Matkę Boską, by wymierzyć wielkość cerkwi (60). 


\section{PODSUMOWANIE}

Przeprowadzone analizy potwierdzają (na wielu poziomach) słuszność zauważonego przez badaczy polemicznego nastawienia Paterykonu. Po pierwsze, Kossow broni niezależności Cerkwii prawosławnej, stawiając tezę: $O d$ Carogrodzkiego Patryarchy Rossya krzćiła śię, od tego y po dźiś dźiē Sakrę Metropolitom swoim bierze (158 marg.). Po drugie, uzasadnia świętość relikwii mnichów pieczarskich. W treści utworu te dwie sprawy nie zawsze są rozdzielone, przeciwnie, propagowanie kultu relikwii kijowskich mnichów wzmacnia argumentację na rzecz niezależności prawosławia.

Polemiczny charakter utworu widać zarówno w strukturze tekstu, gdzie dominują elementy refutacji, jak i w specjalnym użyciu języka, związanym przede wszystkim z probacją. Kształt językowy obu tych obszarów pozwala stwierdzić, że sposób ukształtowania tekstu na opisywanych poziomach potwierdza wspólnotę europejskiej kultury retorycznej, a z Kossowa czyni modelowego reprezentanta humanistycznych wartości i metod ich wyrażania ${ }^{13}$.

Nie sposób jednak nie zauważyć istotnej właściwości jego pisarstwa wyróżniającej jego tekst (przynajmniej w pewnej mierze) od rozemocjonowanych, często mocno ekspresyjnych, a nawet dosadnych polemik autorów piszących w renesansowej Rzeczpospolitej. Jest nią wyraźne, a wynikające z powściągliwości stylu dostojeństwo. Można je do pewnego stopnia uzasadnić predyspozycjami genologicznymi hagiograficznego utworu, ale w większej mierze należy wiązać $\mathrm{z}$ idiostylem. Potwierdzenie tej obserwacji to warte podjęcia i ciekawe poznawczo zadanie. Jego realizacja da bowiem szansę opisać nie tylko właściwości stylu indywidualnego na tle stylów społecznych epoki, ale przede wszystkim pozwoli uzupełnić pejzaż dyskursu polemicznego wieków minionych, niezwykle ważnego elementu życia socjalnego.

\footnotetext{
${ }^{13}$ Warto w tym miejscu przypomnieć, że Kossow był wychowankiem lubelskiego kolegium jezuickiego. W szkołach tego typu gruntowna edukacja retoryczna była jedną z cech charakterystycznych. Na retoryczny wymiar tekstu niewątpliwie miała wpływ także ówczesna praktyka życia społecznego, które uznawało retorykę za najdoskonalsze narzędzie zdolne do poprawnego ułożenia stosunków społecznych. Staranne opracowanie retoryczne tekstu jest więc wypadkową modelu ówczesnej edukacji humanistycznej oraz znaczenia retoryki jako narzędzia sprawnej wymiany myśli i poglądów. Nie bez znaczenia jest również panegiryczny wydźwięk utworu. Jak pisze Hanna Dziechcińska „postawa ta [panegiryczna - uzup. aut.], polegająca na wychwalaniu osoby lub przedmiotu, wiązała się genetycznie z retoryką starożytną, a zwłaszcza z tym rodzajem wymowy, który nazywano genus demonstrativum (614).
} 


\section{BIBLIOGRAFIA}

\section{ŹRÓDŁA}

Kossow, Sylwester. Paterikon abo żywoty ss. Oycow pieczarskich..., 1635, www.sbc.org.pl/ dlibra/show-content/publication/edition/298270?id=298270. Dostęp 25.07.2019.

\section{LITERATURA PRZEDMIOTOWA}

Chomik, Piotr, red. Kościół prawosławny w dziejach Rzeczypospolitej i krajów sasiednich. Zakład Historii Kultur Pogranicza Instytutu Socjologii Uniwersytetu w Białymstoku, Bractwo Prawosławne, 2000.

Duszak, Anna. Tekst, dyskurs, komunikacja międzykulturowa. Wydawnictwo Naukowe PWN, 1998.

Dziechcińska, Hanna. „Panegiryk”. Stownik literatury staropolskiej, red. Teresa Michałowska, Zakład Narodowy imienia Ossolińskich, 2002, ss. 613-616.

Górecki, Artur. „O jezuickiej Ratio studiorum”. Christianitas, nr 58, 2014, ss. 58-69, christianitas.org/ site_media/content/ch58_gorecki2.pdf. Dostęp 10 października 2020.

Hawrysz, Magdalena. Polemiczna twórczość Marcina Czechowica w perspektywie genologii lingwistycznej. Oficyna Wydawnicza Uniwersytetu Zielonogórskiego, 2012.

Klimek, Jolanta. „Prolegomena do poloników kijowskich z XVII wieku”. Język polski. Wspótczesność. Historia, t. 7, red. Władysława Książek-Bryłowa, Henryk Duda, Małgorzata Nowak, Wydawnictwo Uniwersytetu Marii Curie-Skłodowskiej, 2009, ss. 189-203.

Klimek, Jolanta. „Formy aorystyczne w XVII-wiecznych polonikach kijowskich”. Roczniki Humanistyczne. Językoznawstwo, z. 6, 2010, ss. 29-40.

Klimek, Jolanta. „Konstrukcja accusativus cum infinitivo w XVII-wiecznych polonikach kijowskich”. Problemy językoznawstwa wspótczesnego i historycznego, red. Jolanta Sławek, Poznańskie Towarzystwo Naukowe, 2010, ss. 61-75.

Klimek, Jolanta. „Polonika kijowskie - nierozpoznana odmiana polszczyzny XVII stulecia? Rekonesans". Badania historycznojęzykowe. Stan, metodologia, perspektywy, red. Bogusław Dunaj, Maciej Rak, Księgarnia Akademicka, 2011, ss. 91-101.

Klimek-Grądzka, Jolanta. „Uwagi o składni Paterykonu Sylwestra Kossowa (1635)”. Roczniki Humanistyczne. Językoznawstwo, z. 6, 2012, ss. 43-56.

Klimek-Grądzka, Jolanta. „Barbaryzmy w polskich drukach kijowskich (1633-1698)”. Travaux de slavistique. Actes du VIe congrès de la Slavic Linguistics Society, red. Irina Kor Chahine, Charles Zaremba, Presses universitaires de Provence, 2013, ss. 51-61.

Klimek-Grądzka, Jolanta. „Matka Boska w polonikach kijowskich (1635-1638)”. Dawne z nowym tacząc... In memoriam Mariani Kucała, red. Jolanta Klimek-Grądzka, Małgorzata Nowak, Towarzystwo Naukowe KUL, 2016, ss. 119-129.

Klimek-Grądzka, Jolanta. „Про православне монастирське життя в “Патериконі” Сильвестра Косова (1635). Лексичне дослідження”. Poznańskie Spotkania Językoznawcze, nr 33, 2017, ss. 19-32.

Korolko, Mirosław. Sztuka retoryki. Przewodnik encyklopedyczny. Wiedza Powszechna, 1990.

Łużny, Ryszard. „Sylwester Kossow”. Polski słownik biograficzny, t. XIV, Zakład Narodowy im. Ossolińskich - Wydawnictwo Polskiej Akademii Nauk, 1968, ss. 325-327. 
Łużny, Ryszard. „Kijowski siedemnastowieczny wariant cerkiewno-słowiańskiego Pateryka”. Slovo. Časopis Staroslavenskog Zavoda u Zagrebu, no 28, 1978, pp. 35-43, hrcak.srce.hr/index.php?show $=$ clanak\&id_clanak_jezik=22018. Dostęp 15.03.2020.

Łużny, Ryszard. Pisarze kręgu Akademii Kijowsko-Mohylańskiej a literatura polska. Z dziejów zwiąków kulturalnych polsko-wschodnostowiańskich w XVII-XVIII w. Uniwersytet Jagielloński, 1966.

Mead, Margaret. Kultura i tożsamość. Studium dystansu międzypokoleniowego. Tłum. Jacek Hołówka, Wydawnictwo Naukowe PWN, 2000.

Mironowicz, Antoni. Sylwester Kossow. Władyka białoruski, metropolita kijowski. Białoruskie Towarzystwo Historyczne, 1999.

Moszyńska Danuta. „O polszczyźnie Sylwestra Kossowa (Na podstawie wstępu do Pateryka Pieczarskiego z 1635 roku)". Tematy. Księga jubileuszowa w 70. rocznice urodzin Profesora Leszka Moszyńskiego, red. Krystyna Szcześniak, Halina Wątróbska, Wydawnictwo Uniwersytetu Gdańskiego, 1998, ss. 138-143.

Nodzyńska, Ludmiła. „O pierwszym polskim opracowaniu »Pateryku Kijowsko-Pieczerskiego«”. Chrześcijański Wschód a kultura polska, red. Ryszard Łużny, Wydawnictwo KUL, 1989, ss. 219-227.

Nodzyńska, Ludmiła, oprac. i tłum. Pateryk Kijowsko-Pieczerski, czyli opowieści o świętych ojcach w pieczarach kijowskich położonych. Wydawnictwo Uniwersytetu Wrocławskiego, 1993.

Rynduch, Zbigniew. Nauka o stylach $w$ retorykach polskich XVII wieku. Gdańskie Towarzystwo Naukowe, 1967.

Skrukwa, Grzegorz. O czarnomorska Ukrainę. Procesy narodowotwórcze w regionie nadczarnomorskim do 1921 roku w ukraińskiej perspektywie historycznej. Wydawnictwo Naukowe UAM, 2016.

Peretc Volodimir Nikolayevich, „Kiyevo-Pecherskiy Paterik v polskom i ukrainskom perevode”. IV Meždunarodnyy syezd slavistov. „Slavyanskaya filologiya”. Sbornik statyey. Izdatielstvo Akademii Nauk SSSR 1958, ss. 174-210 [Перетц, Володимир Николаевич. „Киево-Печерский Патерик в польском и украинском переводе". IV Международный съезд славистов. „Славянскя филология”. Сборник статей, Издательство Академии Наук СССР 1958, cc. 174-210], books.e-heritage.ru/book/10089415. Dostęp 8.10.2020.

\section{NA STYKU RELIGII, KULTUR I JĘZYKÓW, CZYLI O POLEMICZNYCH ASPEKTACH PATERYKONU SYLWESTRA KOSSOWA}

Streszczenie

W opracowaniu obserwacji poddano szczególny zabytek ze zbioru poloników kijowskich, tj. Paterikon abo żywoty ss. Oycow pieczarskich Sylwestra Kossowa. Jest to piśmienne świadectwo wielokulturowości dawnej Rzeczpospolitej oraz wielopłaszczyznowych relacji polsko-ruskich. Celem szkicu jest wskazanie generycznych elementów polemiki z poziomu kompozycji i pragmatyki tekstu oraz identyfikacja podporządkowanego im repertuaru środków językowych realizujących perswazyjne cele tekstu polemicznego. Analizy pozwoliły wskazać, że polemiczny charakter utworu widać zarówno w strukturze tekstu, gdzie dominują elementy refutacji, jak i w specjalnym użyciu języka, związanym przede wszystkim z probacją. W tym drugim obszarze ujawniono dwie globalne strategie komunikacyjne: uwiarygodnienie treści (na które składa się powoływanie się na źródła historiograficzne i dokumenty oraz dokonywanie zabiegów etymologizujących) oraz apoteoza osób i miejsca 
(którą realizują strategie osadzania przekazu w przeszłości, odwołanie do genealogii, maksymalizacja cnót świętych, sakralizacja zakonnej rzeczywistości). Wśród środków perswazyjnych znalazły się m.in. sylogizmy, argumentum ad verecundiam, argumentum ad baculum, argument $\mathrm{z}$ tradycji, wyliczenie, kontrast. Sposób ukształtowania tekstu na opisywanych poziomach potwierdza wspólnotę europejskiej kultury retorycznej, a z Kossowa czyni modelowego reprezentanta humanistycznych wartości i sposobów ich wyrażania.

Słowa kluczowe: kulturowe relacje polsko-ruskie; europejskiej wspólnota retoryczna; Sylwester Kossow; polemika; strategie komunikacyjne.

\section{AT THE JUNCTION OF RELIGION, CULTURE AND LANGUAGE: ON THE POLEMIC ASPECTS OF SYLVESTER KOSSÓW'S PATERIKON}

\section{S u m m a r y}

This article analyses the text titled Paterikon or the Lives of the Holy Fathers of the Kiev Caves by Sylvester Kossów. It is a unique monument from the collection of Kiev's Polish diaspora; a written testimony of the multiculturalism of the former Polish-Lithuanian Commonwealth and of the multifaceted Polish-Russian relations. The purpose of this outline is: 1) to indicate the generic polemic elements at the level of composition and pragmatics, and 2) to identify the repertoire of language subordinated to them that implement the persuasive objectives of the polemical text. Analyses have shown that the polemical nature of the work can be seen both in the structure, where elements of refutation dominate, and in the particular use of language, primarily associated with probation. In this second area, two global communication strategies were revealed: content authentication (which consists of citing historiographic sources and documents, as well as performing etymologisation procedures), and apotheosis of people and places (implemented by strategies of embedding the message in the past, by reference to genealogy, by the hyperbolisation of saints' virtues, the sacralisation of monastic reality, etc.). The persuasive language includes, inter alia, syllogisms, argumentum ad verecundiam, argumentum ad baculum, argument from tradition, enumeration, and contrasts. The shape of the text confirms the European community of rhetorical culture and makes Kossów a model representative of humanistic values and of the ways of expressing them.

Key words: Polish-Russian cultural relations; European rhetorical community; Sylvester Kossów; polemics; communication strategies. 